\title{
THE PRESENTATION OF CHRISTIANITY IN CEYLON
}

\author{
By J. PAUL S. R. GIBSON
}

The zeal of the missionary recruit who successfully mastered St John iii. 16 in the vernacular on board ship and proclaimed it, on landing, at the street corners should inspire us all, but we rightly question whether he possessed either the wisdom of the serpent or the harmlessness of the dove. Our Master Himself knew His hearers and adapted His message to their understanding. Shall the disciple take less care to know the thought, language, literature and customs of the people he would win for Christ? Specially is this necessary in a land where religious ideals have for thousands of years been stereotyped on the mind, where thought has run in fixed channels for generations and where custom and superstitious rite hold the authority of law. A new gospel strangely presented may strike the few, but it will not win its way into the national consciousness. Patience as well as faith is necessary for the ultimate victory. The sympathy that arises from systematic and accurate knowledge is essential where hearts and minds are to be won.

In venturing to formulate my impressions as to the right method of presenting Christianity to the Singhalese I am fully conscious of the limitations imposed by ten short years' service, by a mind essentially British and by prejudices coming to me from endless generations of western blood. Still, if a personal knowledge of the people, their religion and customs, an acquaintance at first hand with part of the literature, and lastly, a heart that in village and jungle, in social intercourse and close friendship has learned to love - if such qualifications be allowed to count, 
it may be that the thoughts here propounded may prove seed thoughts capable of maturing in abler minds.

I would preface what I have to say by a general warning. Viewed from one standpoint all races are similar-from another they are entirely separated. Differences amongst peoples are more properly differences of emphasis than fundamental differences. Certain tendencies control all human nature but each race has its special bent. When a certain characteristic is asserted of the Singhalese and another of the western or British mind it must be clearly understood that no more is meant than that speaking generally, and allowing for numerous exceptions, in the majority of cases the Singhalese mind would tend to emphasize and therefore tend to act or drift towards one attitude, while the western would adopt another.

I propose in this article to write down impressions gleaned in many places and in various ways. They naturally group themselves along those four great avenues leading to and from the mind of a people : its customs, religious and social; its literature, including folklore as well as books ; its language; and its thought. These forces both converge and interlace. However, they are sufficiently distinct to allow of being differentiated for the sake of analytical clarity.

\section{RELIGIOUS CUSTOM}

Turning first to the religion and its customs let us try to discover the ruling motives. I have studied book Buddhism in translation and in the original but it is not primarily with that we have to deal. We are concerned with the religion of the masses, that curious blending of atheistic Buddhism with the gods of Hinduism and the personality of Christianity. It is the people and not the books that are to be won.

Over all spreads the Karma shroud. To Buddha it may have been an incentive to free-willed action. The masses it has deadened. To them it is Fate. Happiness 


\section{The Presentation of Christianity in Ceylon 343}

and sorrow are by all interpreted fatalistically. The fruit of what has been must be. This fatalistic attitude, in all but the devotees, extends to all action. Not only what comes, as we might say, accidentally, but what would appear to us to lie within their own hands is regarded in the same light. The old fallacy grips their mind. It is fated we shall live or die-if to live, why waste money on the physician; if to die, likewise? 'Why act at all?' is the lethal attitude. By 'act' is meant such mental grappling with any situation as will lead to deliberate, willed, objective action. Few of the people doubt or argue against Christianity. Still fewer bestir themselves to appropriate it.

With the devotee it is different. To him the present is rather seed of the future than fruit of the past. He presses forward, and like the runner for a time forgets the prize in the joy of the race. I have seen the pilgrims from every corner of the island crowded together in the stifling heat of the great court waiting for hour after hour in almost breathless silence, with intense expectation portrayed in the very passivity of their waiting, until the sacred doors opened and the temple governor appeared bearing the revered relic, venerated as the tooth of Buddha; then there burst one sound from ten thousand throats, 'Sadhu, Sadhu ! Hail, Hail!' I have seen them again toiling up the almost precipitous sides of Adam's Peak, repeating together the stanzas chanted first by their leader, only breaking off to burst into the shout of 'Hail, Hail!' as now and again the majestic top towering above them became visible through some break in the trees and stood out clear, bathed in the moonlight. On and up, fainting and breathless, heedless of cold, of fatigue and exhaustion, till with a culminating effort they almost leap up the last hundred feet panting out the object of their devotion. ' It is our Buddha we have come to worship; it is our Buddha we have come to worship.' Then forcing a path through the less frantic and more chilled crowd, they 
make their way tolthe Dagoba and offer in kind the devotion already expressed in their person. Old and young make the pilgrimage up the 7500 -foot mountain, and as I stood watching the bell rang out twenty-seven strident notes to tell the number of an aged devotee's ascents. Not all climb in this spirit, and yet it is not few who do so, and the cheerful peaceful 'Karunawei' ('Peace be with you') with which those descending greet those coming up tells of some inward gain to mind and spirit won by this act of devotion.

Here indeed there is passion, whether it be the passive and calm passion of long waiting or the active and heated passion of achievement.

Moreover, those who most of the year live in apathetic indolence will from time to time turn from national custom to such a pilgrimage, gradually, as they leave their villages in twos and threes and meet the constantly growing throng of pilgrims all like-minded with themselves, the sense of common aim, of association with the throng, kindles the fires latent within them, the flames of passion burst through the enveloping apathy and they, like the more regular devotees, live once again.

But to what is all this passion directed ? Their Buddha they know to be dead. $\mathrm{He}$ is never thought of as alive and influencing them, though the various relics are regarded as possessing miraculous efficacy. It is in no sense passionate devotion to a living personality. Can reverent memorizing of the lifeless dead be such an incentive? I have no doubt in my own mind that the secret of all this power lies in the forward look and not in the retrospect. Such deeds are meritorious, they go to prepare something better for the doer, for ' at the hour of death merit is a good friend' [Dh. 331]. On the pilgrims' return there is no thought of any benefit having accrued to the Buddha, but a very real feeling of security in the merit stored up for future use, such as one feels when the pass-book shows a fat balance. There is a fascination in collection 


\section{The Presentation of Christianity in Ceylon 345}

and accumulation of any kind, and perhaps in the East more than anywhere is the practice of storing developed. There is but little doubt that heaping together merit for oneself lies behind this passion, though during the performance of the act of devotion such ulterior motive doubtless recedes into the background.

This idea naturally leads one to another marked characteristic of the religious life, namely, its ego-centricity. Full as the Buddha's teaching is of kindness to others and care for them, the whole is based on the doctrine that each life is an isolated unit, unaffected by Karma and unable to modify the Karma of another. An attempt has been marle to prove by quotations that merit is transferable. I see little trace of this being a current belief and I cannot but feel that the attempt in certain quarters to emphasize it now is largely due to Christianity having shown the very real deficiency of Buddhism on this point.

There are cases in which a devotee performs acts of merit on behalf of some member of the family, and the various ceremonies performed by relatives after the death of a relation must be regarded as at least partially vicarious in their operation, yet these are very secondary in the mind of the people, and would appear to deal only with minor benefits.

The strong and universal opposition to the idea of Christ having won the salvation of humanity is sufficient evidence that the conception of vicarious suffering, or merit as efficacious in matters fundamental, is not generally held. The Buddha's last words unmistakably strike this note of separation and individuality, even as Christ's strike the note of the continued efficacy of His eternal presence. The Buddha may be regarded as a light in the world but, except as exemplar, in no vicarious sense the saviour of mankind. I see so far no reason to waver in my conviction that Buddhism is in essence an exclusively individualistic philosophy. Growing experience is deepening the conviction. 
In many ways the reflex action of rejected Christianity is strong and can be traced in the thoughts of priests and people. On a train journey I was once given a concise compendium of Buddhist philosophy by a priest. I listened without arguing and was astounded at the extent to which his version was coloured by the ideas and terminology of Christianity.

A philosophy of salvation by works and of the heaping up of merit tends to complacency and self-satisfaction, whether among so-called Christians or Buddhists. This doctrine deadens the sense of sin. If the escape from $\sin$ lies wholly with ourselves, surely it is not such a terrible thing after all. Most will readily acknowledge that they commit sins, but in very few is there any real sense of being a sinner. This attitude is not uncommon in the West but seldom so pronounced as here, where it forms a thick wall through which the Christian message of forgiveness can only be heard with difficulty. It is only natural that where life is regarded as an evil in itself, a holy life should not be so great an incentive as it is to those in whose ears ring the call of God, 'Be ye holy for I am holy.' Whatever in the slightest degree lessens the appeal to immediate holiness must at the same time lessen the sense of the failure to be holy-e.g. of the sense of sin. Holiness becomes obedience to precepts, not approximation to a personality. So also any doctrine, such as Karma, that so minimizes the effect of death as to put future chances of salvation on a par with those now given-and thus reduces the intensity of the appeal 'now is the day of salvation'-must necessarily also weaken the sense of sin. This is true whether we are extremists or more moderate in our interpretation of the finality of the opportunities given for salvation in this life.

The concept of lack of relation is pushed to its utmost limit with regard to the question of evil. Each man heaps up his own merit, so also he sins his own sins. One cannot share in a sinful act without doing the act itself. I had 
my first striking illustration of this when my Pundit's son was ill. Since then $I$ have constantly run across it. We advised a boiled egg, well knowing a Buddhist would not care to boil an egg. However the next morning the son had had a boiled egg. Who boiled it ? It was bought boiled at the market. Did he not share that man's guilt ? How could he? The man who boiled it sinned and probably got compensated by extra payment. There the matter ended. No soiling influences would pass from the sinful Moor who boiled it to the cautious buyer who so carefully kept free from the evil act. No amount of discussion could make him see that he was his brother's keeper.

Worship too is, as would be expected, largely individualistic. Individuals go morning and evening to the temple and offer flowers. There are meetings for hearing the law read in Pali and for taking the five or eight vows, but there is no corporate prayer, and but little that could be termed corporate praise, for there is no deity to praise and no one to whom prayer can be offered. There is reciting of the law instead of hymn singing and there are responses, but it is the conglomeration of units and not the communion of saints. This essential self-centredness finds frequent expression in the Dhammapada, which as Fausböll remarks contains 'some of the fundamental texts of the Buddhist religion.' A few pada will illustrate the point.'

When the wise one puts off sloth for zeal, asconding the high tower of wisdom he gazez sorrowless upon the sorrowing crowd below. Wise himself, he looks upon the fools as one upon a mountain-peak gazing upon the dwellers in the valley.

If on a journey thou canst not find thy peer or one better than thyself, make the journey stoutly alone: there is no company with a fool.

A man is his own helper: who else is there to help? By self-control man is a rare help to himself.

Even for great benefit to another let no man imperil his own benefit. When he has realized what is for his own good, let him pursue that earnestly.

Alone when eating, alone when sleeping, alone when walking, let a man strongly control himself and take his pleasure in the forest glade.

1 The Translations are taken from The Buddhist $W$ ay of Virtue in the 'Wisdom of the East' series. Nos. 28, 61, 160, 166, 305. 
Selfishness and indifference to the sorrow of others were certainly very far from the Buddha's mind, just as carelessness of self and of one's ultimate salvation were from St Paul's when he wrote (Romans ix. 3) : ' For I could wish that I myself were anathema from Christ for my brethren's sake, my kinsmen according to the flesh.' Both are speaking hyperbolically, both are driving the truth to extremes. But it is in such extremes that the fundamental underlying trend of thought becomes evident. The Buddha centres on self; St Paul, following his Master, centres on non-self.

Lastly, I am inclined to consider that related to this is the fact that the Singhalese, as compared with ourselves, seldom use touch to convey feelings. It is all done by look or nod, they do not touch each other. There is no hand-shake, that subtle method of telling others our innermost selves, no pat on the back to stir, no hand laid on shoulder in sign of sympathy or encouragement. One of my unsolved problems is to find how to replace this lost instrument, for even if $\mathrm{I}$ try to express myself in this way to my students it conveys little or nothing to them.

Touch, however, is not altogether unknown as a means of expression, though it is of special rather than general use. Hands are laid on the head by an aged father in token of blessing. The hands of a child are placed between the hands of a guardian or teacher to whom the child is being entrusted. Naturally, too, among certain classes the western habit is being adopted.

Not even a slight survey such as we are making would be complete without reference to the strict adherence to the prohibition as to taking life. This does not eliminate cruelty nor the placing of animals where they must die, nor the ill-use of animals, but the law is obeyed to the letter, and very rigidly. Life, however, is not taken, and the doing so is regarded as a serious fall. Animals in pain are left to die, and I have seen a sick elephant left to starve. The fisherman feels no stings of conscience as he plies his trade. 
He merely drags a live fish out of the water. So too the Moor is made to kill the needed food for such as feel compunction. That which has been killed is not forbidden, only the actual killing. Vermin flourish under this regine. One rest-house keeper on being asked whether his resthouse were clean exclaimed, 'Oh yes, I Christian, I kill fleas.' So it is that slaughter and Christianity find a common ground. Devotees take the most elaborate precautions lest they should inadvertently cause the death of some visible life. No account is apparently taken of the multitudinous bacteria just hidden from our unaided sight and which perish by their millions through man's use of medicine or the boiling of water or cooking of food.

Where there is spirit, there is life and growth. Buddha deliberately eliminated the god idea and that of personality from the region of practical consideration. Some maintain he denied both ; most at least agree that he deemed them caviar to the public. No race can be thus mentally separated from direct consideration of God's Personality in the Holy Spirit without paying the penalty. The emphasis laid on the glories of the past only reveals the lack of development in the race. Nothing struck me more at Anuradhapura as I visited the remains of thousands of years ago than the similarity between the designs and execution of buildings dating from the second century and those of the twelfth. At Polonnaruwa, which dates from the sixteenth century, similarity with Anuradhapura strikes one more than difference. The creative mind of the Buddha impressed his generation, but soon the influence faded and correct imitation replaced progressive genius. Stand before Ely Cathedral and examine its tiers. The most casual observer can trace the change, the growth of idea, the mind of the architect from pillar to pillar. The expert is able to date an arch to within twenty-five years from the progressive mind revealed in stone.

Much the same strikes me as to the art of the country. Work done in the schools shows that much talent is latent. 
Expression lacks true life and tends to be crude and tawdry. This is true whether we think of the usual decorations of temples, or houses. Such criticism might doubtless be made of the untrained people in all races. Here, however, there is little to represent the higher art aspirations we find elsewhere. We need hardly wonder at this, seeing that it is always the Divine that has prompted the highest endeavours of the artist.

It must be remembered that very good work is done in conventional designs in Ceylon. The human form, however, has never been recognized to be the temple of the Holy Ghost but rather the seat of all evil. It is not surprising, therefore, that this form of art has never risen beyond the crude and formal. There is no life in any statue or picture, even of the Buddha himself.

From the stereotyped to the formal is but a step and that step has been taken. The many wonderful ideals of Buddhism have lost their life and are but part of the accepted rite. I think of that priest who was lamenting to me the theft of his goods by rascally villagers. He repudiated the suggestion that he was their priest and the representative of the law that was to reform them. No, they were past reform, he must go and live somewhere where people were good. The Dhamma had lost its power.

I remember again that wonderful ordination ceremony for the priesthood when the ordained arrives literally caparisoned with the world's pomp. After taking the vows before the great semicircle of priests, piece by piece, cloth of silver and chains of gold, rings for hand and jewel for- body are removed, until the priest-to-be stands bereft of all his glory. The head is shorn, over his form is draped the yellow robe and into his hand the begging bowl is placed. Henceforth for him poverty, chastity and meditation. It is the great renunciation symbolized. What inspiration might lie behind this form! But it was not so, either to the ordained or to the people. To me it seemed a time for prayer, to them a time for eating and drinking, and 
for careless chatter accompanied by the pop of the gingerbeer bottle. The meaningful ritual remained, passed down the ages, but the spirit was dead. Is this to be wondered at when there is no prayer? Buddhism is strictly logical, if nothing else. The Buddha is not, God is not, spirit there is not; then to whom should they pray? But the iron bars of logic cannot make a cage for the soul within man. One of the most curious of religious phenomena is that of the Buddhist devotee who, having offered his flowers at the Pansala, before the image of the Buddha and in memory of his greatness, makes his way to the Hindu temple there to pray to the local deity. The wayside shrines are often used in this way. It is as natural to man to pray as to breathe, and no precept can prevent it. Yet prayer can be and has been eliminated from formal Buddhism with the direst effect.

\section{SOCIAL CUSTOM}

As we turn to the social and family life there is much that is pleasing. A dignity and reticence pervades the whole system. Gentleness and courtesy' greet one. Lavish hospitality and readiness to please, even at great inconvenience, characterize the majority. When they are lacking, so-called western culture can usually be traced. The Singhalese gentleman bears on him the stamp of that brotherhood which binds the truly and inwardly cultured of all races; his friendship is above the price of rubies.

There is a great love for children, no house is without them and if the gifts of the gods are not vouchsafed then a child is adopted. Such a child often becomes the legal heir. Children reverence their parents and obey them in a wonderful way, specially after reaching years of discretion. The hold of parent on child is immense. There is a beautiful custom still in vogue. On the day of the New Year the children assemble and kneeling before the father implore his forgiveness on all the past, and having received it, reverently rise. Reverence is both expected and given. 
There is a recognized code by which the respect due is accurately measured. It is shown in speech by the honorific terminations to nouns, pronouns and verbs, and by the position of the hands and arms in greeting, as well as by the general demeanour.

Family honour, where it is felt, is held sacred and vindicated at any cost whatsoever. Even Christians find it hard to place the dictates of truth and virtue above those of the family. On the other hand, family feuds are frequent and long remembered. Nearly every family is broken up into factions.

The promiscuous giving of doles to the poor by all has its vicious economic side, but while it encourages begging it has effectively prevented the need of almshouses and of poor laws, at least amongst the village population. Begging is a most lucrative profession, as the Trinity College Social Service League has discovered in the course of its attempts to find suitable work for the Kandy beggars.

The social order is dominated by individualism. This characteristic, which is the direct result of belief in Karma, is to my mind the secret of the glorious past having faded away, and unless remedied will long and unduly delay the highest aspirations of Singhalese nationalism. Apart from the family, and not always there, there is no co-operation, no cohesion, no mutual trust on any large scale. The good of the community is subject to the good of the individual. Family is against family, headman against villager, caste against caste. Jealousy prevents progress. If a villager succeed in some way in doing better in his crop than his neighbour, the only result is theft or indignity. Emulation and eager happy rivalry are little known. One administrator in a certain district by very heavy penalties for larceny of this type did succeed in encouraging local industry, but he was soon removed and his successor did not carry on the system and very soon things were as before. Bribery is inherent. It is in the blood, so much so that the simplest request even amongst friends is usually 
prefaced by a gift. These gifts are not usually associated with any definite idea of bribery, but it is realized that to preface a request by a gift makes its refusal more difficult. At any rate the refusal will be couched in courteous terms and the applicant need not lose face-no small consideration. A Singhalese proctor told me his experience was that any man would give false evidence against his neighbour for five rupees. When speaking of this vice to my students $I$ in trepidation quoted this statement. I was greeted with ' $\mathrm{Oh}$, Sir, he will do it for a plate of rice.' This lack of trust has hindered the growth of trade amongst the Singhalese. They have the ability and yet it is the Moors and Tamils who hold practically the whole trade of the island. Almost every Singhalese village has its Moor boutique. Again it is for the same reason that the educated Singhalese vote for a Tamil to represent the educated Ceylonese on the Legislative Council rather than agree on a candidate of their own nationality whom they could almost certainly put in.

The native practitioners exemplify the same principle. Many invaluable medicines and drugs are known to them. Their treatment of certain diseases is certainly wiser than ours. Their power of dealing with fractures by massage is remarkable. But in most cases the secret belongs to an individual and not to the profession. It is used for personal prestige rather than for the public weal. It is treasured until at the last it is passed on as a family heirloom to favourite son or disciple. But death often arrives without a harbinger and the secret is lost to the community.

I know of one case where the compound fracture of the thigh of a man of seventy was declared at the hospital to be incurable under three months. The patient went to a Singhalese Vedarala and was walking in a fortnight. The Vedarala was offered free training in England if he would undertake to publish a work dealing with his method of cure. Nothing would induce him to make public the family secret. The passion to cure, the sense of the honour 
and dignity of the ministry of healing, the professional instinct to overcome disease and ward off death is but seldom found.

Man in Buddhism is an independent unit whose life and salvation lie in his own hands. Anything that expresses that independence is good. Caste is not infrequently used to express this principle. The highest caste may at times feel so secure that it can afford to ignore the presence of lower castes, though even this is by no means general. The middle castes often assert their position by what appears to us outrageous rudeness but which is not felt to be such even by the ones who suffer it, and it tends to be regarded as the correct thing by those who perpetrate it. Even an advanced Christian told me with evident pride how at a wedding some lower caste man had been shamed. The lower expect it and see in it a sign of greatness and the higher are not always backward.

Gratitude and a sense of obligation are essentially attributes dependent on relationship. Therefore, as might be expected, the first is seldom expressed and the latter avoided. The beggar who receives a dole does not say 'Thank you,' but 'May your merit accrue!' His Karma has brought him the gift; it must have come anyhow. Why thank the giver more than we do the postman? We are only truly grateful to active agents in our welfare and not to mere instruments. If any thanks are due, surely they are due from the giver to the beggar for providing a good means for making merit? A gift is received more with condescension than with expressed gratitude even by Christians, who though they certainly feel grateful are restrained from evincing it by ingrained habit and other subconscious influences. The repugnance to any sense of obligation is best illustrated by the following. I asked a student of mine whether he saw any injustice in the parable of the labourers in the vineyard who all got one penny. For a time he saw none, but eventually said he thought if 


\section{The Presentation of Christianity in Ceylon 355}

any one had any right to complain it was the later ones, who each received more than their due and were therefore left in the uncomfortable position of being obligated to the Master. Much water would pass under London Bridge before such an answer was obtained from an English youth.

Another fundamental characteristic is the desire to avoid the unpleasant at any cost, even that of truth or honour. The worst evil is losing face. No request is ever denied, but the promise is seldom fulfilled. It is not necessarily expected it should be fulfilled. The method of acquiescing will reveal whether the promise is real or not, but neither party will show it. Denial is rudeness, for which the Singhalese have absolutely no toleration. It is the prime sin. This is why the parable of the two sons loses its whole force. The one was polite and said 'Yes' and went not. Why should he go ? The other's discourtesy no amount of subsequent work could redeem. There is definite aversion to grappling with the difficult. The villagers of the north-western province have no harder difficulties to overcome than their Tamil neighbours in the north, and yet the north-western province is a jungle and Jaffna a garden.

It necessarily follows that direct reproof is seldom given and is regarded as an insult. One's Pundit will never, except under great pressure, correct a mistake of grammar or pronunciation. Later in the lesson the correct form will be given in some sentence by the teacher, and it is for one to notice the difference. Even a Christian of long standing explained to me he really preferred this way when I corrected his English, though naturally he did not take my more open corrections as insults.

So also confession of a fault is rare, and when made can usually be regarded as a great sign of grace. The confession may be implied by word or act, but it is not for you to show by word or sign that you have comprehended.

Connected with the intense dislike for reproof or ridicule a curious but almost universal trait is to be noticed. $\mathbf{A}$ 
Singhalese cannot bear being called names. It may be a survival of the time immemorial idea that there is something vital in a name; that it not only represents but is. To many nations the names of their god or gods are unutterable. But whatever the cause the fact is certain. A boy would far rather be caned than either laughingly or in anger called a rabbit, or a goat, or for the matter of that any name. The most passionate appeal I ever had of one student against another was that the lower caste one of the two had called the other a bull (synonymous with fool). Complaints of servants or others seldom deal with cruelty or actual abuse of power, but nearly always with verbal abuse. I mention this at length, as much influence is lost by the missionary who thoughtlessly uses epithets - in many cases almost as endearment, seldom in real annoyance.

It is easy to see that subtlety and concealment are the very marrow of the daily life. Nothing is free and open. Our openness distracts them. One man told me that he and his best friend never spoke freely as we do to each other; all was insinuated and suggested and their friendship consisted in the power mutually to comprehend each other. He told me the trouble with English people was that just as you were getting to like them they went and opened their hearts to you and the spell was broken. Nothing is expressed. At least expression is bad form, whether it be gratitude or anger, pleasure or hate. This is true to a limited extent even among Christians of long standing. Do you wonder they find it hard to feel drawn to us? This trait frees the roads of much that is unseemly, and more of this self-control on Hampstead Heath on Bank Holiday might be a good thing.

(To be concluded) 